\title{
METHODS IN NPD FOR STARTUPS: EVALUATING STAGE GATE, DESIGN THINKING \& LEAN STARTUP KEY CONCEPTS WITH STUDENTS
}

\author{
Margot SANDY \\ Imperial College London
}

\begin{abstract}
In the last 5 years, the demand for new goods online increased 350 percent from $\$ 8$ billion to $\$ 36$ billion in estimated online sales and still some growth in brick and mortar stores. [1]

This upward trend in consumer products continues as competition expands globally, emphasis on strategies for innovation gain momentum and an ever-increasing focus on customer engagement. Big business dominates this sector, but there is still a need for entrepreneurial new businesses, like start-ups, to help spur/sustain job creation and provide global market competition, especially with new products, to aid in economic growth [25]. Yet, these types of companies experience extreme uncertainty and risk [14], [20] in the often-unfamiliar territory of new product development.

This paper presents the results of a 2-month study from an entrepreneurial simulation to develop new consumer products with groups of university students. Students were used in this study to mirror some environmental conditions, demographics and general characteristics of startups. Significant methods and best practices were introduced into the study to evaluate the effect of the decision making in a population with limited familiarity with different innovation processes.

In the end, this exercise shed light on the effect of structured tools introduced into a homogeneous discipline environment where rationale for decisions increased, but the most effective use of tools dissimilar to own discipline impacted the overall results.
\end{abstract}

\section{Keywords: NPD, stage gate, start-ups, design thinking, lean startup}

\section{INTRODUCTION}

Extreme uncertainty is a characteristic that many new ventures or startups that develop new products or services have in common [23], [14], [20]. Some researchers, lack of experience is one of the key principles that perpetuates this state when pursuing a new field [26]. So, in the last decade with the explosion of different entrepreneur friendly platforms to encourage the creation of new ideas/businesses, like Crowdfunding, Angel Networks and idea submission outlets, it is believed that a missing element in the process is present. This need for further exploration is emphasised with accompanying research concerning high risk of failure associated with these new types of businesses [8], [3].

\subsection{Literature Review}

More often than not, startups have a "just do it" approach [23] with little structure to corral their innovation or new product efforts. They lack routines for dealing with new team members and coordinating activities for delivering their products or services [2], skills in the specific areas of expertise needed [6] [19], knowledge of networks to promote the product [5] and information about what is needed for the customer satisfaction [20] [29] [17]. On the other hand, traditional firms or large businesses that typically operate in this sector were evaluated to understand more about the processes or systems that are most consistently adopted in organisations developing new products.

The academic work on commercialising new products is very rich in models, methods, best practices and frameworks for how organisations turn ideas into something tangible. Each area of literature with a different approach or perspective from; engineering, innovation management, design, manufacturing to marketing. The approaches mirroring each discipline's perspective throughout the new product creation process. Further frameworks have been developed by prominent contributors in the design engineering field. Wynn and Clarkson who have categorised the existing work into Procedural, Analytical, Abstract 
and Management Science/Operations Research (MS/OR) areas [30]. Other researchers have compared engineering design models over the last 50+ years identifying stages consistent with (a) establishing a need, (b) analysis of a task, (c) conceptual design, (d) embodiment design, (e) detail design and/or (f) implementation [16]. Nevertheless, the innovation method used most frequently in some form in industry (80\% in North America) is Robert Cooper's Stage Gate [7] [13]. This is a linear model with phases and gates as outlined in Howard's 2008 review [16] which has specific deliverables to move through from ideation to launch process. However, as there is more of a push to develop products faster, more cheaply and to be more innovative [22], large companies are bringing new creative strategies into their firms such as Design Thinking [4] and Lean Thinking [23] to address the rigid nature that is often associated with the Stage Gate process [7]. Design Thinking considers the end user by applying empathy and Lean Thinking has a goal of incorporating market feedback as soon as possible into the product.

The current study attempts to evaluate startups in a simulated entrepreneurial environment with students to evaluate the effects of industry best practices on a typically unstructured process of developing new products in the uncertain world of a startup. Students and universities have often played a role in supporting the innovation efforts in problem solving [11]. Since students share some of the traits of startups such as limited knowledge of a new area, high tolerance for risk, ambition and willingness to try something new, the educational environment was judged appropriate as a basis for the study.

\subsection{Research Question / Objectives}

The hypothesis for this study is that if startups or students are given a more structured process for developing their ideas, then the decision-making process will improve with the knowledge gains from structured tools. This improvement shown would ultimately increase their likelihood of success in the marketplace based on the literature demonstrating that experience as being key to startup success [10]. Furthermore, the time and use of each tool was evaluated for (a) proper use of the tool and (b) knowledge gains from the tool. Thus, the research question is: what is the effect of structured tools in a simulated startup environment with users that have a low familiarity of the typical process?

\section{METHOLODOLOGY}

The study itself was 2 months long for 1 product design and development classroom of students at a prominent technical university in the North-eastern part of the United States. The research methodology was based on analysis of quantitative data using an online survey approach [24] as the tool for obtaining and evaluating information.

\subsection{Context Setting}

The university setting was to mirror different characteristics of the population within the startup industry by sector, gender breakdown and location. The students were all from the mechanical engineering field in the $4^{\text {th }}$ or $5^{\text {th }}$ year of a five-year technical programme. At this point in the curriculum they would have completed all core classes for the academic programme and had at least one six-month paid co-op or internship. Their experience with formal design engineering training would be limited to the current class.

When comparing the university students age with those of successful startup founders, the difference is quite drastic. To explain, based on a recent study of startup founders, the average successful founder age is 40 years old [15]. Since this paper is evaluating experience or familiarity with innovation methods / development procedures and working off the assumption that experience will increase with age, [9] then the main difference in the two population profiles was a higher experience level with successful startup founders. See Figure 1. The study attempted to demonstrate a way to fill the gap of experience with the addition of tools that were derived from years of experience.

\section{Startup Profile}

- Sector: Tech Industry

- Gender Breakdown: 88\% Male, 12\% Female [27]

- Location: NY state

- Average successful startup founder age: 40 [15]

\section{University Student Profile}

- Sector: Technical University

- Gender Breakdown: 88\% Male, 12\% Female

- Location: NY state

- Average classroom age: 21 yrs.

Figure 1. Comparison of Startup Profile vs. University Study Student Profile 


\subsection{Study Design}

The classroom was divided into 4 groups consisting with 4-5 participants each with the goal of each group generating a product idea and making design decisions in route to the development of a prototype with the possibility for commercialisation. Each group had team members with assigned roles and responsibilities to represent the real-world roles that would take place in a larger company. These roles included Marketing, Design, Engineering, Manufacturing and Project Management [28]. There were 5 tools introduced throughout the study to represent different discipline approaches to developing new products. See Table 1. Each tool had a control version representing an industry standard version performed by a member of the tool discipline. The students work was compared to the control tool and then rated on a Likert scale [21] with the range being proper use.

Table 1. Tool / Discipline Summary

\begin{tabular}{|c|c|c|c|c|c|}
\hline Discipline & $\begin{array}{c}\text { Project } \\
\text { Management } \\
\text { / Innovation }\end{array}$ & Engineering & Marketing & Design & Manufacturing \\
\hline $\begin{array}{r}\text { Best Practice / } \\
\text { Method / } \\
\text { Methodology } \\
\text { or Tool }\end{array}$ & $\begin{array}{l}\text { Evaluating } \\
\text { approaches }\end{array}$ & $\begin{array}{c}\text { Killer } \\
\text { Variables / } \\
\text { Stage Gate }\end{array}$ & $\begin{array}{l}\text { Competitive } \\
\text { Benchmark }\end{array}$ & $\begin{array}{l}\text { Mind map / } \\
\text { Design } \\
\text { Thinking }\end{array}$ & Lean Thinking \\
\hline Description & $\begin{array}{c}\text { Determining } \\
\text { approaches } \\
\text { by identifying } \\
\text { markets first } \\
\text { or technology } \\
\text { first }\end{array}$ & $\begin{array}{c}\text { Determining } \\
\text { constraints } \\
\text { (technological, } \\
\text { market, } \\
\text { environmental) }\end{array}$ & $\begin{array}{l}\text { Evaluating } \\
\text { existing or } \\
\text { similar } \\
\text { products on } \\
\text { the market }\end{array}$ & $\begin{array}{l}\text { Evaluating } \\
\text { the end user } \\
\text { by what they } \\
\text { see, think, } \\
\text { feel, their } \\
\text { pains and } \\
\text { gains }\end{array}$ & $\begin{array}{c}\text { Obtaining } \\
\text { customer } \\
\text { feedback early } \\
\text { in the process } \\
\text { to incorporate } \\
\text { into product } \\
\text { design }\end{array}$ \\
\hline Source & [28] & [7] & [28] & {$[18]$} & {$[23]$} \\
\hline
\end{tabular}

\subsection{Data Collection}

The data collection took place throughout the entire 2 months. Initially, information was collected from each student regarding (a) demographics, (b) whether the students had previously thought about a new product idea, (c) their interest in developing physical, digital or physical and digital products and (d) their familiarity with different development best practices, methods and methodologies. After the initial individual online surveys, information was obtained after each group used a new tool and then evaluated for proper use. Then, the final survey was given to obtain which tool was the most helpful in making decisions. This final survey was also presented to the students using the Likert scale [21].

\section{RESULTS}

Most students had previous product concept thoughts prior to coming to class (that had not been pursued), much of the interest was in developing physical products rather than digital services (82\%) and in general there was low familiarity with prominent methodologies in developing products (76-82\% not familiar with each tool). The level of familiarity was due to little exposure to design engineering subjects in the current curriculum unless student pursued electives based on their own interests, was curious about the topic or was exposed to a methodology during an internship. See Figure 2. 


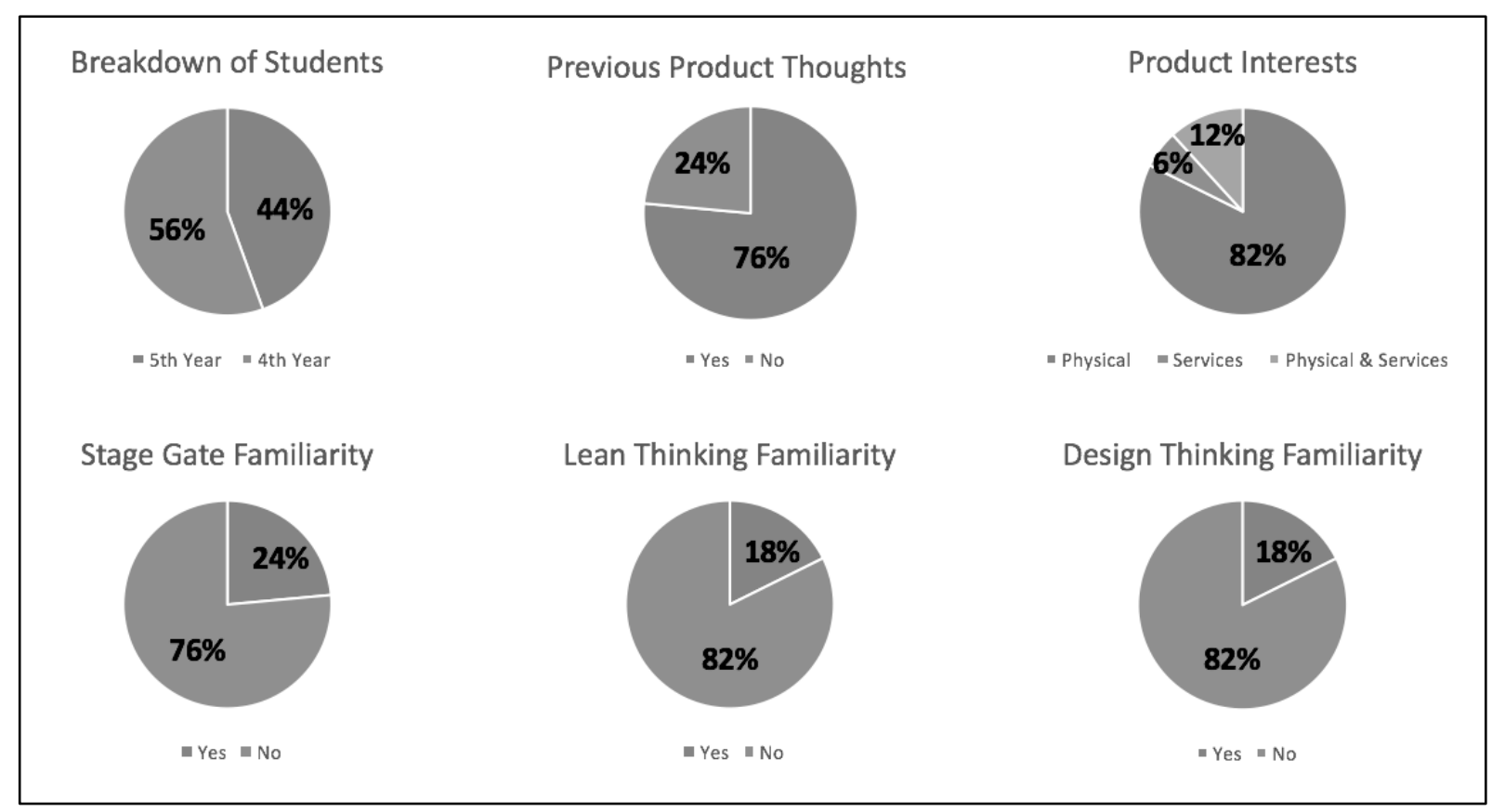

Figure 2. Initial Survey Summary Results

In terms of the time to use each tool, the range of time spent for each was similar, with groups averaging 1-3 hours per tool. The proper use of each tool based on comparison to the control tool varied after evaluating each deliverable. It was clear that the students did have trouble properly developing Mind maps and the approach with interacting with customers for feedback varied per group.

Finally, when the students were asked to rank which tools were most helpful in making design decisions, the Competitive Benchmarking tool ranked highest, followed by the innovation approaches and lean thinking tools. The Mind map tool was identified as the least helpful for the students when the information from the Likert scale was analysed [21].

\section{DISCUSSION}

The main purpose of the paper was to evaluate whether the introduction of industry and academic best practices would encourage better decision making in a startup-like environment. Overall, there were mixed results with the data. In general, the students could provide more rationale as to why decisions were made as well as additional considerations for other areas of the product development process. Where there seemed to be some confusion was when the main discipline of the class had to use a tool that was unlike their own main specialty. For instance, the class representation consisted mainly of students with engineering and manufacturing backgrounds and there was notable difficulty when reviewing the deliverables for fields that were unlike theirs. This was evident in the use of the design tool (mind map) and when evaluating the different markets for innovation strategy. Since the process of new product development incorporates technical and non-technical experience, there should be explicit instruction that caters to the understanding of the discipline using the tools. To further explain, the tools where more critical thinking was needed were also ranked less helpful, so this could be a case of unfamiliarity of thinking in a certain way or a reflection of lack of critical thinking required in university in some instances. This diagnosis would have to be further studied to make a conclusive statement about this problem area.

Other interesting findings were that the four product concepts developed by the different groups were completely different from each other, yet this occurred using the same process / tools. The categories of products ranged from modular furniture, to a niche consumer product to an extension of a product line to a piece of equipment where new technology was the differentiation. The fact that these new product areas reflected areas with initial low familiarity by the students but showed that they could explore and make credible cases for further development was a key finding. This could be consistent with the findings from the Duchesneu and Gartner study relating to the impact of planning being an influencer of startup success [12] if the products went on to commercialisation. 


\subsection{Limitations}

Opportunities for further study would be for replication on a larger scale. The study was limited by 1 classroom of students and 1 discipline of students. It would be worth reviewing the study with different disciplines to see whether there were continued struggles with using non-similar discipline tools.

\section{REFERENCES}

[1] 2018 Consumer Products Industry Outlook | Deloitte US [WWW Document], 2018. URL https://www2.deloitte.com/us/en/pages/consumer-business/articles/consumer-products-industryoutlook.html (accessed 11.8.18).

[2] Arrow K. (1974) The Limits of Organisation. New York: Norton.

[3] Berggren E. and Nacher T. 2001. Introducing new products can be hazardous to your company: use the right new- solutions delivery tools. Academy of Management Executive 15 (3), 92-101.

[4] Brown T. and Katz B. 2009. Change by design: how design thinking transforms organisations and inspires innovation, 1st ed. ed. Harper Business, New York.

[5] Campbell C. (1992) 'A Decision Theory Model for Entrepreneurial Acts', Entrepreneurship Theory and Practice 17(1): 21-7.

[6] Cooper A.C., Gimeno-Gascon F. and Woo C. (1994) 'Initial Human and Financial Capital as Predictors of New Venture Performance', Journal of Business Venturing 9: 371-95.

[7] Cooper R.G. 2011. Winning at new products: creating value through innovation, 4th ed. ed. Basic Books, New York.

[8] Crawford C.M. 1987. New product failure rates - facts and fallacies. Research Management 22 (5), 9-13.

[9] Cressy R. (1996). Are business startups debt-rationed? Economic Journal, 106(438), 1253-1270.

[10] Delmar F. and Shane S. 2006. Does experience matter? The effect of founding team experience on the survival and sales of newly founded ventures. Strategic Organisation 4, 215-247. https://doi.org/10.1177/1476127006066596

[11] Dodgson M., Gann D. and Salter A. 2008. The management of technological innovation: strategy and practice, New ed., rev. and updated. ed. Oxford University Press, Oxford; New York.

[12] Duchesneau D.A. and Gartner W.B. 1990. A profile of new venture success and failure in an emerging industry. Journal of Business Venturing 5, 297-312. https://doi.org/10.1016/08839026(90)90007-G

[13] Edgett S.J.n.d. The Stage-Gate ${ }^{\circledR}$ Model: An Overview 5.

[14] Eisenhardt K.M. and Martin J.A. 2000. Dynamic capabilities: what are they? Strategic Management Journal 21 (10/11), 1105-1121.

[15] How Old Are Successful Tech Entrepreneurs? [WWW Document], n.d. Kellogg Insight. URL https://insight.kellogg.northwestern.edu/article/younger-vs-older-tech-entrpreneurs (accessed 3.6.19).

[16] Howard T.J., Culley S.J. and Dekoninck E. 2008. Describing the creative design process by the integration of engineering design and cognitive psychology literature. Design Studies 29, 160 180. https://doi.org/10.1016/j.destud.2008.01.001

[17] Johnson P. (1986) New Firms: An Economic Perspective. London: Allen and Unwin.

[18] Kelley D. and Kelley T. 2013. Creative confidence: unleashing the creative potential within us all. Crown Business, New York.

[19] Klepper S. (2001) 'Employee Startups in High-tech Industries', Industrial and Corporate Change 10(3): 639-74.

[20] Knight F. 1921. Risk, Uncertainty and Profit. Houghton-Mifflin, New York, NY

[21] Likert R. (1932) A technique for the measurement of attitudes. Archives of Psychology, no.140.

[22] Nichols K. 1992. Better, Cheaper, Faster Products - by Design. Journal of Engineering Design 3, 217-228. https://doi.org/10.1080/09544829208914758

[23] Ries E. 2011. The lean startup: how today's entrepreneurs use continuous innovation to create radically successful businesses, 1st ed. ed. Crown Business, New York.

[24] Robson C. 2011. Real world research: a resource for users of social research methods in applied settings, 3. ed. ed. Wiley, Chichester.

[25] Schmitz J. (1989). Imitation, entrepreneurship, and long-run growth. Journal of Political Economy, 97(3), 721-739. 
[26] Shrader R. and Siegel D. (2007). Assessing the relationship between human capital and firm performance: Evidence from technology-based new ventures. Entrepreneurship: Theory \& Practice, 31(6), 893-908.

[27] Startup Founder Demographics | PitchBook Data Viz [WWW Document], n.d. URL http://dataviz.pitchbook.com/founders/ (accessed 3.6.19).

[28] Ulrich K.T. and Eppinger S.D. 2016. Product design and development, Sixth edition. ed. McGraw-Hill Education, New York, NY.

[29] Von Mises L. (1949) Human Action: A Treatise on Economics. New Haven, CT: Yale University Press.

[30] Wynn D.C. and Clarkson P.J. 2018. Process models in design and development. Research in Engineering Design 29, 161-202. https://doi.org/10.1007/s00163-017-0262-7. 